Agricultural

Marketing

Service

December 2013

\title{
Grain And Oilseed ShipMent Sizes and Distance Hauled by Rail
}

Marvin Prater Adam Sparger

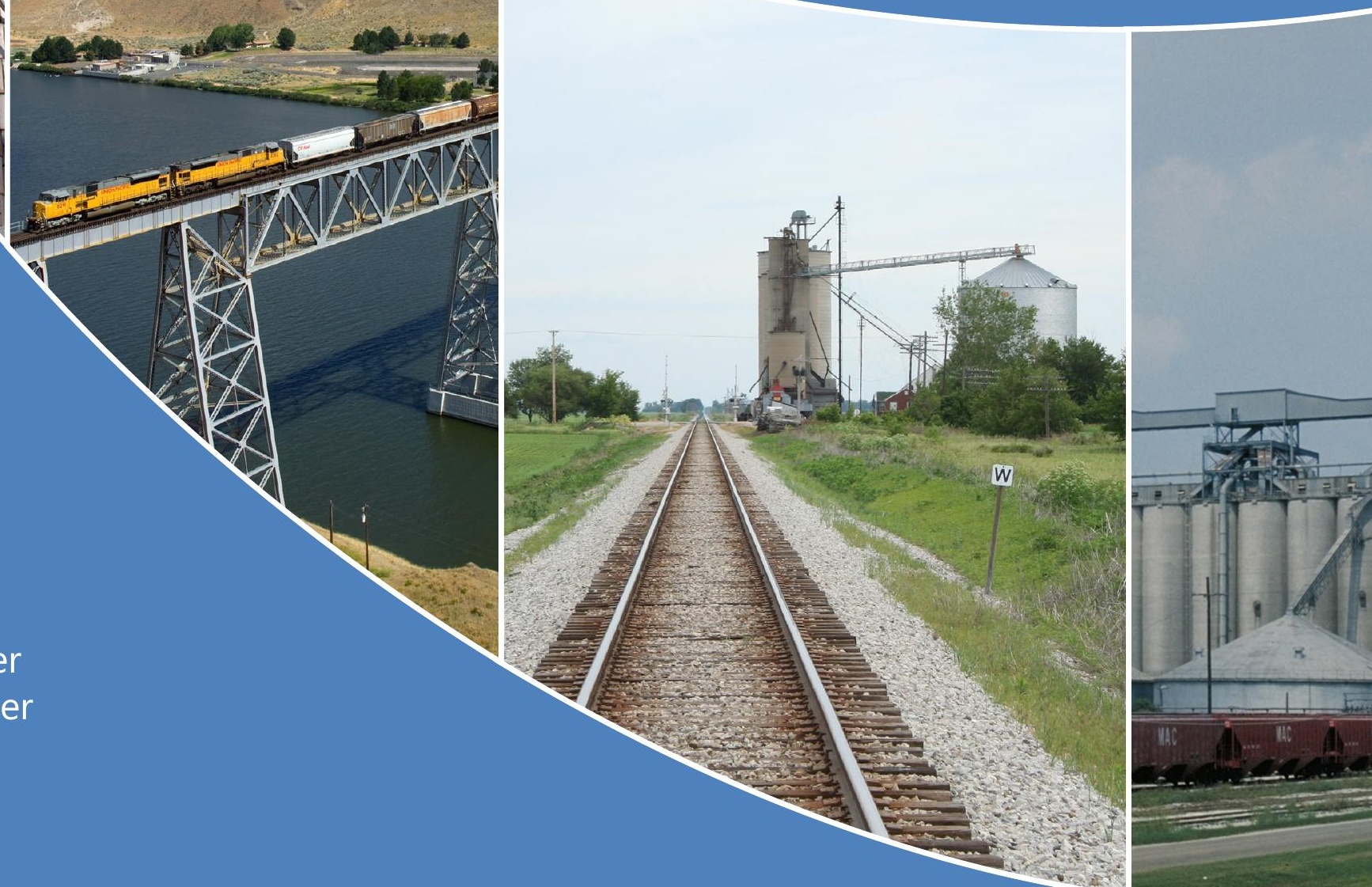




\section{Preferred citation:}

Prater, Marvin E. and Adam Sparger. Grain and Oilseed Shipment Sizes and Distance Hauled by Rail. U.S. Department of Agriculture, Agricultural Marketing Service. Washington, DC. December 2013. <http://dx.doi. org/10.9752/TS059.12-2013>

This paper was presented to the 53rd Annual Transportation Research Forum and published in its proceedings. <http://www.trforum.org/forum/proceedings.php?year=2012>

\section{Cover photo credits (left to right):}

- Huw Williams

- David Gubler

- Wikimedia Commons

- USDA

The U.S. Department of Agriculture (USDA) prohibits discrimination against its customers. If you believe you experienced discrimination when obtaining services from USDA, participating in a USDA program, or participating in a program that receives financial assistance from USDA, you may file a complaint with USDA. Information about how to file a discrimination complaint is available from the Office of the Assistant Secretary for Civil Rights. To file a complaint of discrimination, complete, sign and mail a program discrimination complaint form, available at any USDA office location or online at www.ascr.usda.gov, or write to: USDA, Office of the Assistant Secretary for Civil Rights, 1400 Independence Avenue, S.W., Washington, D.C. 20250-9410. Or call toll free at (866) 632-9992 (voice) to obtain additional information, the appropriate office or to request documents. Individuals who are deaf, hard of hearing or have speech disabilities may contact USDA through the Federal Relay service at (800) 877-8339 or (800) 845-6136 (in Spanish). USDA is an equal opportunity provider, employer and lender. Persons with disabilities who require alternative means for communication of program information (e.g., Braille, large print, audiotape, etc.) should contact USDA's TARGET Center at (202) 720-2600 (voice and TDD). 


\title{
Grain and Oilseed Shipment Sizes
}

and Distance Hauled by Rail

\author{
Marvin Prater \\ Adam Sparger
}

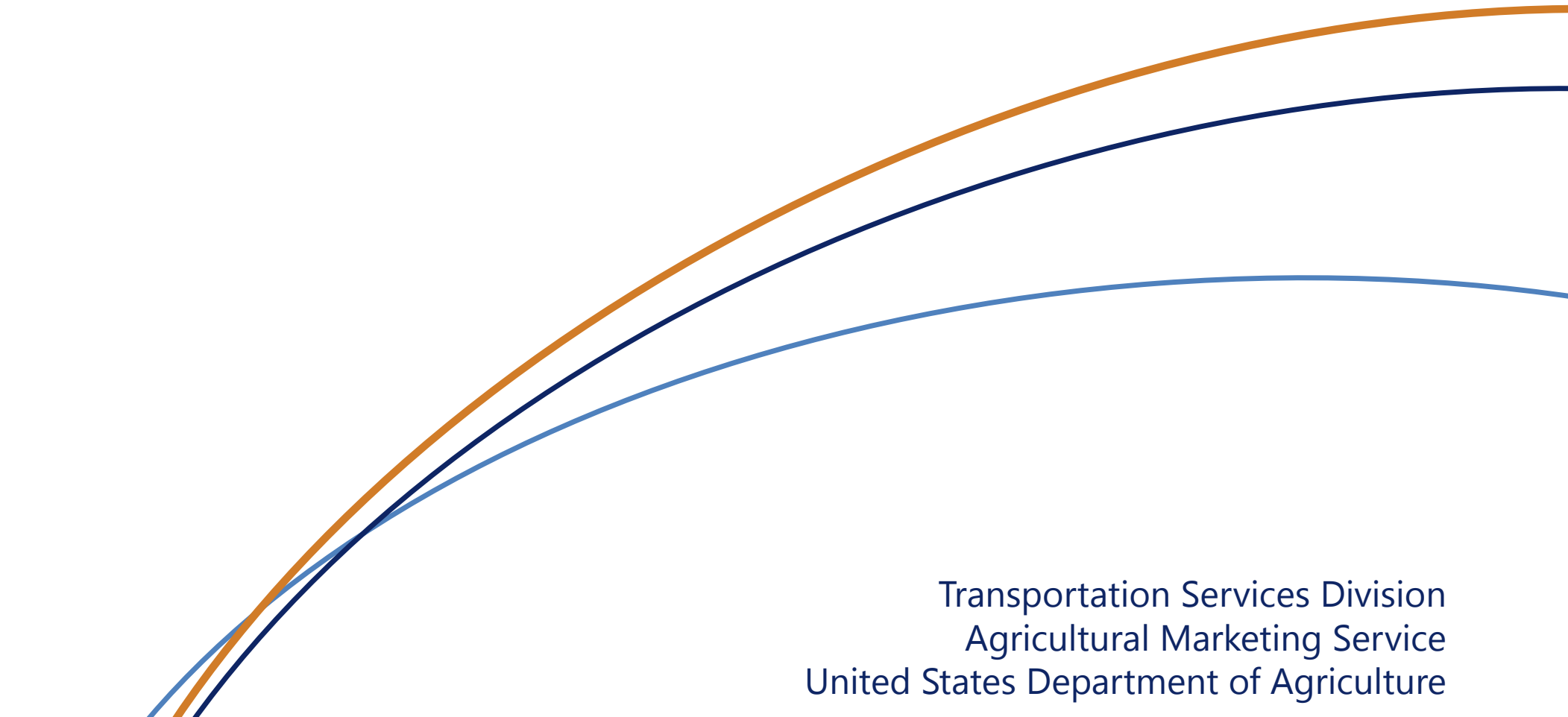


<smiles>C=C=C=C=C=C</smiles> 


\section{EXECUTIVE SUMMARY}

Grain and railroads have an interdependent relationship. Grain is one of the most important commodities for railroads. It is the primary agricultural commodity moved by rail, comprising 7.9 percent by tons of all commodities, 94 percent by tons of all farm commodities, and 8.4 percent of total rail revenue in 2009. In turn, railroads represent a vital component of the grain network, hauling 33 percent of all grain transported in the United States in 2007. As domestic and export markets have evolved, railroads have continuously made efficiency strides through shuttle trains and the length of haul. Since 1994, grain and oilseed transportation has moved from small shipment sizes to shuttle-size shipments (75 or more railcars) for many grains and oilseeds, reflecting the lower costs of shuttle-size shipments, an increase in the number of domestic destinations capable of unloading shuttle-size shipments, and increased grain and oilseed exports in some years. In addition, the length of haul has increased for grains and oilseeds, reflecting competitive advantages of rail compared to truck on longer hauls, lower rail tariffs per mile for longer hauls, and changing grain and oilseed markets. However, development of the shuttle market has occurred differently among grain types and has not been explored at the individual commodity level.

This paper uses the Surface Transportation Board Confidential Waybill Samples to quantify the changes in shipment size and length of haul for each major grain and oilseed (corn, soybean, wheat, sorghum, and barley) from 1994 to 2009. Changes in shipment size and length of haul are compared to production and usage changes for each of the major grains and oilseeds to gain more insight into the underlying reasons behind the changes.

Categories of shipment size used in this paper are:

- 1 to 5 railcars

- 6 to 49 railcars

- 50 to 74 railcars

- 75 or more railcars

Categories for distance shipped are:

- 20 to 500 miles

- 501 to 1,000 miles

- 1,001 to 1,500 miles

- More than 1,500 miles

This procedure improves upon earlier analyses of the grain shuttle-size market by exploring the changes at the individual commodity level.

The shuttle market for each grain has developed differently because exports, production, and usage have been different despite the overall push towards larger and longer hauls by the railroads in order to maximize efficiency. In 1994, the dominant size of shipment for all 5 grains was 6 to 49 railcars. However, there were initial differences in the lengths of haul: corn, soybeans, and barley were hauled mostly between 20 and 500 miles in 1994, but wheat and sorghum were hauled between 501 and 1,000 miles. By 2009, corn and soybeans were mostly hauled more than 1,500 miles, but the predominant category for each of the other grains did not change. 
Wheat has been the most consistent of the five grains over the period of study with very little change in exports, production, or usage. As such, it has had the fewest changes in shipment size or length of haul; the dominant shipment size and length of haul have remained the same throughout the time period. In contrast, a production increase in corn and soybeans due to corn-based ethanol and soybean exports has led to more shuttle-sized shipments of these commodities. Exports, the rise of large dairies, and a shift in animal production to regions distant from corn and soybean production regions have resulted in lengths of haul in excess of 1,500 miles becoming predominant. Soybeans have had the most dramatic change in length of haul because of increased exports and shipments to large animal feed regions which are not as susceptible to truck competition, as evidenced by rail's increase in market share. On the other hand, corn's length of haul has been mostly more than 1,500 miles only since 2008 when more ethanol plants were built, leading to stronger truck competition for the shorter movements to ethanol facilities and taking away some of rail's share.

Shuttle markets have developed differently for sorghum and barley despite decreased production in both. Sorghum for ethanol production and a higher percentage of exports among total usage have led to an increase in shuttle-sized shipments even though less is being exported overall. Barley production has declined due to corn and soybeans being more profitable, and barley exports have declined without a strong export demand. The predominant barley shipment size of 6 to 49 railcars and length of haul between 20 and 500 miles makes rail shipment of barley more susceptible to truck competition and has caused rail to lose market share over the time period. 


\section{Contents}

Introduction

1

Objective

2

Literature Review

3

Changes in Crop Usage

4

Methods

7

Results

8

Changes in Rail Shipment Sizes

8

Changes in Distance Shipped

12

Changes in Market Share of Rail Transportation 15

Conclusion 17

References

18 


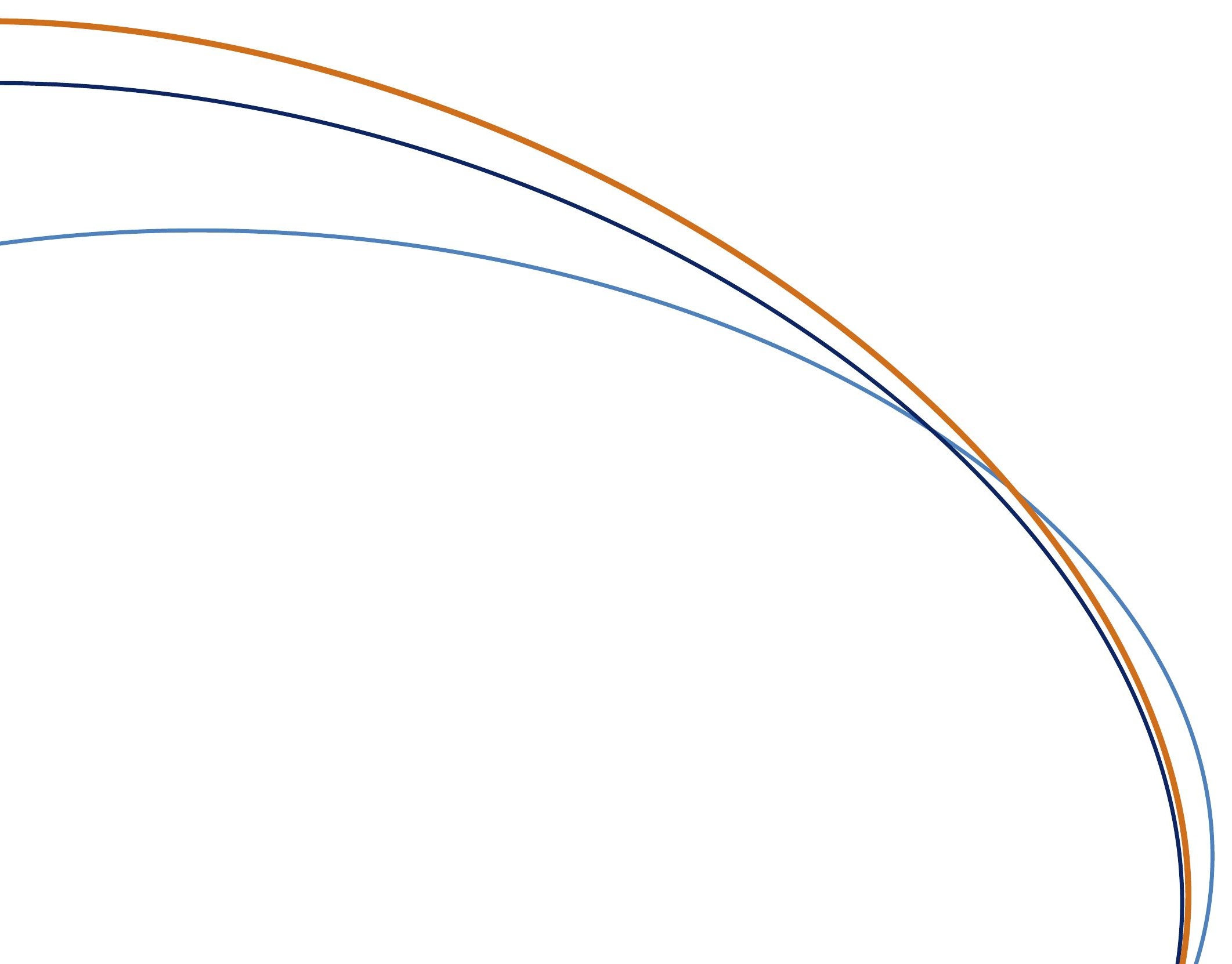


Grain and railroads have an interdependent relationship. Grain is one of the most important commodities for railroads. It is the primary agricultural commodity moved by rail, comprising 7.9 percent by tons of all commodities (Association of American Railroads (AAR), 2010b), 94 percent by tons of all farm commodities (AAR, 2010a), and earned 8.4 percent of total rail revenue in 2009 (AAR, 2010b). In turn, railroads represent a vital component of the grain network, hauling 33 percent of all grain transported in the United States in 2007 (Marathon and Denicoff, 2011).

As domestic and export markets have evolved, railroads have made continuous strides in efficiency by increasing shuttle-size shipments. ${ }^{1}$ Since 1994, grain and oilseed transportation has moved from single-car shipment sizes to shuttle-size shipments (75 or more railcars) for some grains and oilseeds, reflecting the lower costs of shuttle-size shipments, the number of domestic destinations capable of unloading shuttle-size shipments and, in some cases, increased grain and oilseed exports. However, development of the shuttlesize market has occurred differently among grain types and has not yet been explored at the individual commodity level.

Railroad promotion of shuttle-size shipments has resulted in shuttle-size shipments becoming the dominant shipment size for the movement of corn, soybeans, and sorghum (Surface Transportation Board (STB), 19942009). Although shuttle-size shipments of wheat comprise 36 percent of wheat shipments, the dominant shipment size remains 6 to 49 railcars -47 percent of the 2009 wheat tonnage (STB, 1994-2009). Shipment sizes of 6 to 49 railcars for barley are the dominant size of shipment, with shuttle-size shipments ranging from 0 percent to 4 percent of total barley tonnage (STB, 1994-2009).

Railroads have also gained efficiency by increasing the length of haul for grains and oilseeds, reflecting the comparative advantages of rail transportation over trucks for longer hauls, lower rail tariffs per mile for longer hauls, and changes in the grain and oilseed markets. In 1994, lengths of haul for corn and soybeans were principally between 20 and 500 miles. In 2009, however, the predominant length of haul for these two crops had become greater than 1,500 miles (STB, 1994-2009). In contrast, the primary length of haul for wheat and sorghum has not only stayed the same since 1994, but it has also become even more predominant. In 1994, the average length of haul for wheat and sorghum was between 501 and 1,000 miles, representing 40 percent and 34 percent of total movements, respectively. By 2009, hauls of this length had increased to 51 percent and 54 percent of total movements (STB, 1994-2009). For barley, the predominant length of haul remains 20 to 500 miles and lengths of haul of 501 to 1,000 miles have increased.

1 The majority of trains consisting of 75 or more railcars are believed to be shuttle-train movements. Each railroad defines shuttle-train movements a little differently; some require a minimum of 75 railcars, while others require up to 120 railcars. A common element is that the locomotives are never detached from the cars as the train moves from origin to destination and then back to the same or another origin. Another common element is the presence of loading and unloading time incentives. Because they don't meet these criteria, some movements of 75 or more railcars are not shuttle movements. For this reason, we use the term "shuttle-size shipment," which includes both shuttle and non-shuttle movements. 
Although there has been some study into how railroad incentives for shuttle trains have changed the movement of grain, the studies have been made at aggregate levels. The Association of American Railroads publishes the percentage of rail tonnage of grain by movement type (AAR, 2010b). However, this data is for grain as a whole, rather than by each grain. In addition, it does not distinguish between shipment sizes of 50 to 74 railcars and those of more than 75 railcars, which include shuttle trains.

AAR data shows that unit trains (more than 50 railcars) increased from 34 percent of the grain tonnage in 1985 to 60 percent in 2008 (AAR, 2010b). The tonnage of grain moved by single-car movements ( 1 to 5 railcars) decreased from 36 percent in 1985 to only 12 percent in 2008 (AAR, 2010b). The tonnage of grain moved by multiple-car shipments (6 to 49 railcars) decreased from 30 percent in 1985 to 28 percent in 2008 (AAR, 2010b). AAR publishes the average length of haul by grain and by year, but does not break the data down by mileage category. The AAR data shows that the average length of haul has increased for all the major grains, but the grains differ in the amount the length of haul has changed (table 1).

Table 1. Average Length of Haul by Grain Type (miles)

\begin{tabular}{|l|c|c|c|}
\cline { 2 - 4 } \multicolumn{1}{c|}{} & $\mathbf{1 9 9 4}$ & $\mathbf{2 0 0 9}$ & Percent change \\
\hline Corn & 660 & 1,129 & 71 \\
\hline Soybean & 596 & 1,331 & 123 \\
\hline Wheat & 781 & 1,037 & 33 \\
\hline Sorghum & 745 & 1,144 & 54 \\
\hline Barley & 794 & 738 & -7 \\
\hline
\end{tabular}

This paper analyzes grain movements for individual grains based upon shipment size and length of haul. It explores railroad incentives in the shuttle market and provides background data on grain usage and production in order to gain a better understanding of the development of the grain transportation market between 1994 and 2009. 
The partial deregulation of the railroad industry substantially changed railroad regulations, allowing railroads to innovate and change rates to reflect the cost efficiency and market demand of different movements. This partial deregulation facilitated the introduction of new service options (Wilson and Wilson, 2001). Partial deregulation has greatly accelerated the replacement of single-car grain movements with lower-cost multiplecar and unit-train shipments (MacDonald, 1989). In addition, railroads were free to set prices to encourage longer hauls, in which they have a substantial comparative advantage over trucks (Wilson and Wilson, 2001).

Changes in the agricultural industry also have encouraged the trend toward unit and shuttle trains, as well as the associated consolidation of grain-handling facilities. These factors include investments in processing plants, increased size of livestock and poultry feeding operations, increased economies of scale for unit- and shuttle-train-loading facilities, larger farms, and increased producer ownership of semitrailer trucks, which allow the producer to haul longer distances (Prater and Klindworth, 2000, pg. 19). Also, shifts within the feed industry are creating greater demand for transportation, especially long-haul transportation (U.S. Department of Agriculture, Agricultural Marketing Service (USDA/AMS), 1998).

Multiple-car rates were one of the earliest pricing innovations and were responsible for major railroad efficiency gains (Wilson and Wilson, 2001). Prior to the advent of unit trains, most grain was shipped from small country elevators in single- or multi-car movements, depending on need. Car tariffs were the same per car no matter how many cars were ordered. These grain cars were then combined with other freight traffic to form a full train. In the early 1960s, Southern Railways began offering lower tariff rates for grain shipped in multi-car units. Other railroads adopted this practice with 26-car units in the late 1970s and 52-car units in the 1990s. Cars ordered in 26- or 52-car units received lower per-car rates. However, even these larger units still needed to be assembled at rail yards and combined into complete trains (Wilson and Wilson, 2001).

In the 1990s, further innovation took place with unit trains in which an entire unit of 50 or more cars hauling a single commodity would ship from the same origin to the same destination without being split en route. Railroads prefer to assemble full trains before moving because no more labor is required to operate a shuttle train of 100 cars than a unit train of 50 cars and switching costs are the same regardless of the number of cars (USDA/AMS, 1998). Recognizing the economies of shipment size, railroads have encouraged the use of unit and shuttle trains.

Shuttle trains are a further development of unit trains, offering improved efficiency to railroads and additional incentives to shippers. In addition to eliminating excess switching, shuttle trains greatly increase the traffic capacity of rail lines that are heavily used because they minimize the time lines are blocked while picking up shipments (Prater and Klindworth, 2000, pg. 11). Shuttle trains differ from other unit trains in that they are entire trains, usually between 75 and 120 cars, that haul a single commodity between a single origin and destination and are operated on a continuous cycle for a specified length of time under contract. Since railcars in shuttle trains cycle up to 36 times per year, compared to only 15 times per year for railcars in normal service, the use of shuttle trains increases railcar utilization and is extremely attractive to railroads (Prater and Klindworth, 2000, pg. 19). Rail tariff rates for multiple-car and shuttle-train shipments reflect these labor and efficiency savings (Casavant, et al., 2011) (U.S. Departments of Agriculture and Transportation (USDA/DOT), 2010, pg. 253). Railroad promotion of shuttle-train shipments includes lower tariff rates, incentives for rapid loading and unloading, and incentives for the number of annual trips. 
Financial incentives from the railroads for unit and shuttle trains have had the effect of consolidating small country elevators into facilities with greater capacity that are capable of loading unit or shuttle trains. In their promotion of unit and shuttle trains, railroads offer incentive rates and economic development incentives to encourage shippers to build train loading stations. A dedicated shuttle loading facility requires a large investment on the part of the shipper organization, an investment that is not usually shared by the railroad. For example, Sarmiento and Wilson (2005, pg. 1034) found that the cost of upgrading to a shuttle-loading facility was between $\$ 5$ to 10 million across nine States in 2001 . As such, the associated costs do not always justify the benefits of upgrading to such a facility. In another example, Vachal et al. (1999) analyzed elevators for hard red spring wheat in the Northern Plains based on production density, rail dependence, railroad spreads, and customer desires and found that only elevators that handled in excess of 10 million bushels could justify the $\$ 2$ million investment to upgrade to a 100 -car-unit-train-loading facility.

Based on this evidence, it is likely that the profitability of individual grains and their quantities and proportions influence an elevator's decision to upgrade to a shuttle-loading facility. This in turn should influence the proportions of grain traveling in shuttle-size movements. A final factor affecting shipment size is related to export movements. Kenkel, Henneberry, and Augustini $(2004, \mathrm{pg}$. 3) state that unit and shuttle trains are most likely destined for large domestic processors and exports while single and multicar shipments are most likely destined to smaller domestic processors.

In addition to larger shipment sizes, railroads prefer longer hauls due to the additional cost savings. Class I railroads have encouraged longer hauls following deregulation because their per-mile costs decrease appreciably as the length of haul increases. As long as additional switching is not required, longer hauls result in little additional expense to the railroad (Prater and Klindworth, 2000, pg. 11) (USDA/AMS, 1998).

\section{Changes in Crop Usage}

In addition to changes in railroad services, there have also been developments in the way grain is used domestically and abroad, in the international marketplace, and in the amounts that are produced and exported. The production of corn and soybeans has increased and that of wheat, sorghum, and barley has declined. As prices have changed to reflect new supply and demand equilibriums, the size and distance of grain shipments has been affected as well.

Corn usage has changed markedly since 1994. In 1994, 58 percent of corn usage was for feed and residual usage, compared to only 39 percent in marketing year (MY) 2009 (fig. 1) (U.S. Department of Agriculture, Economic Research Service (USDA/ERS) Feed Grains Database). Usage for alcohol for fuel use (ethanol) increased from 6 percent in 1994 to 35 percent in 2009. A byproduct of ethanol production is distillers' grains (DDGS), which are used to feed animals, offsetting the reduced corn usage for
Figure 1. Corn Use, Marketing Year 2009

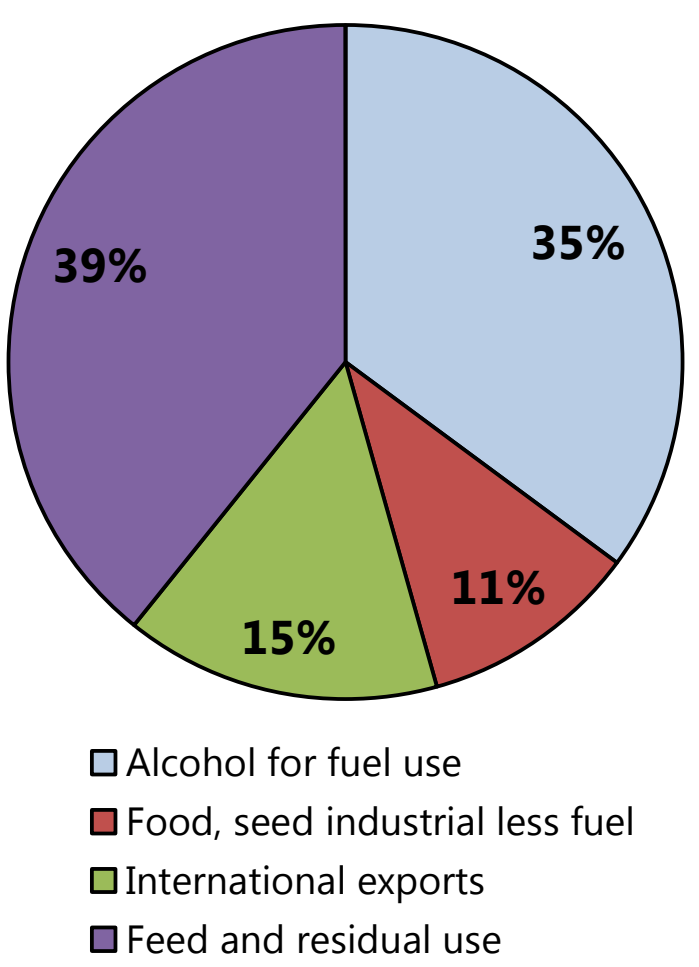

Source: USDA Economic Research Service, Feed Grains Database 
feed. Food, seed, and industrial use (less fuel usage) decreased from 13 percent in 1994 to 11 percent in 2009. Corn exports have decreased from 23 percent of usage to 15 percent, but corn production has increased 30 percent between 1994 and 2009. The quantity of corn exports decreased only 9 percent, from 61.0 million tons in 1994 to 55.4 million tons in 2009. The use of corn to produce ethanol does not necessarily reduce the amount of corn available for exports because exports depend on price and production in other countries. For instance, nearly as much corn was exported during 2005 (59.7 million tons) and 2006 (59.5 million tons) as in 1994. In addition, considerably more corn was exported in 2007 (68.2 million tons) than in 1994.

From MY 1994 to MY 2009, U.S. soybean production increased 34 percent in response to high world demand for meat, milk, and eggs, which use soybean meal as a high-protein livestock feed. Soybean tonnages exported have increased 79 percent, from 25.2 million tons in MY 1994 to 45.0 million tons in MY 2009 (USDA/ERS Soybean Yearbook Tables). Exports to Asia accounted for much of this, with a 259-percent increase from 7.7 million tons in MY 1994 to 27.8 million tons in MY 2009 (U.S. Department of Commerce). Consequently, export usage increased from 35 percent of total use in 1994 to 45 percent in 2009 (fig. 2). Crush use of soybeans decreased from 59 percent of total use in 1994 to 52 percent in 2009.

Wheat usage has not changed markedly since 1994. Exports and food are still the primary uses of wheat, comprising 45 percent and 41 percent, respectively, of 2009 wheat use (fig. 3) (USDA/ERS Wheat Yearbook Tables). Exports have averaged 48 percent of U.S. wheat production from 1994 to 2009, but are variable, ranging from 40 percent to 62 percent of production because of changes in world markets and world production. Because the wheat fed to livestock tends to be of a lesser quality and almost all U.S.-grown wheat is food quality, feed use of wheat was only 11 percent during MY 2009; food-quality wheat is too expensive to use as feed.
Figure 2. Soybean Use, Marketing Year 2009

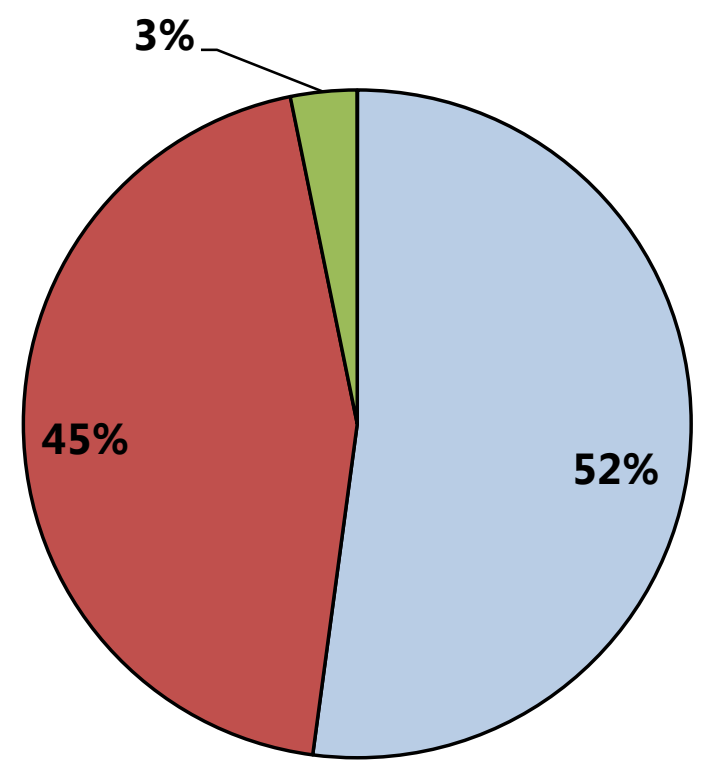

$\square$ Crush use

$\square$ International exports

$\square$ Seed, feed, and residual

Source: USDA Economic Research Service, Soybean Yearbook Tables

Figure 3. Wheat Use, Marketing Year 2009

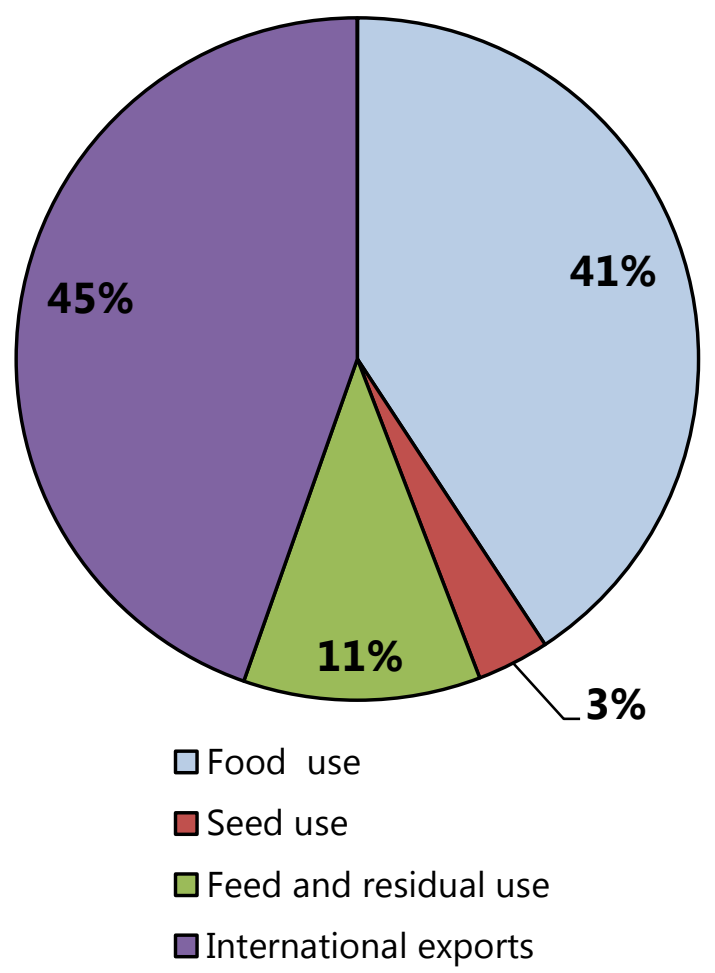

Source: USDA Economic Research Service, Wheat 
Sorghum usage has changed substantially since 1994. In 1994, 61 percent of sorghum usage was for feed and residual, compared to only 35 percent in 2009 (fig. 4) (USDA/ERS Feed Grains Database). Sorghum usage for food, seed, and industrial changed from 3 percent in 1994 to 23 percent in 2009. A large portion of this change is due to usage of sorghum to produce ethanol. Sorghum exports, as a percentage of usage, have also increased from 36 percent in 1994 to 42 percent in 2009, although the tonnage of sorghum exports decreased from 6.2 million tons to 4.6 million tons. The reduction in export tonnage is due to a decrease in sorghum production-43 percent from 1994 to 2009.

U.S. barley production decreased 39 percent from 1994 to 2009 because corn and soybeans were more profitable to grow. Barley use for feed and residual decreased from 49 percent in 1994 to 22 percent in 2009 (fig. 5) (USDA/ ERS Feed Grains Database). Food, seed, and industrial use of barley increased from 37 percent in 1994 to 75 percent in 2009. Barley exports decreased from 14 percent of use in 1994 to 3 percent in 2009 because of decreased Asian consumption of U.S. barley.
Figure 4. Sorghum Use, Marketing Year 2009

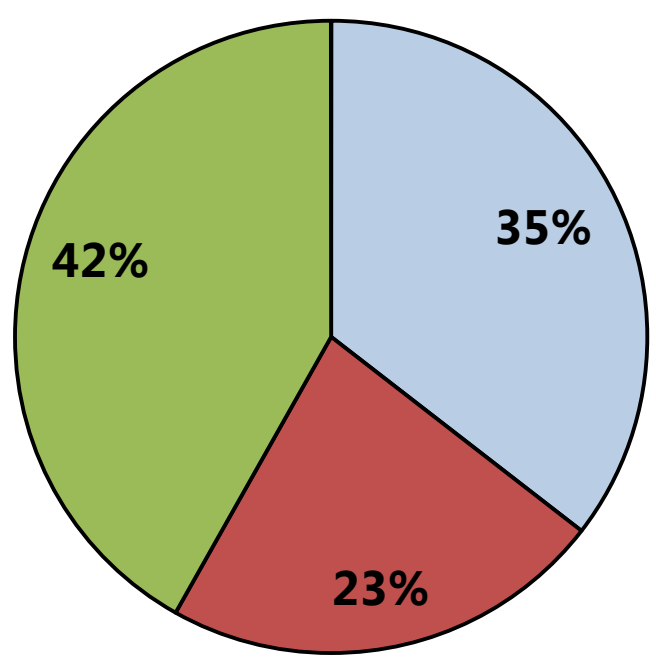

$\square$ Feed and residual

$\square$ Food, seed, and industrial

$\square$ International exports

Source: USDA Economic Research Service, Feed Grains Database

Figure 5. Barley Use, Marketing Year 2009

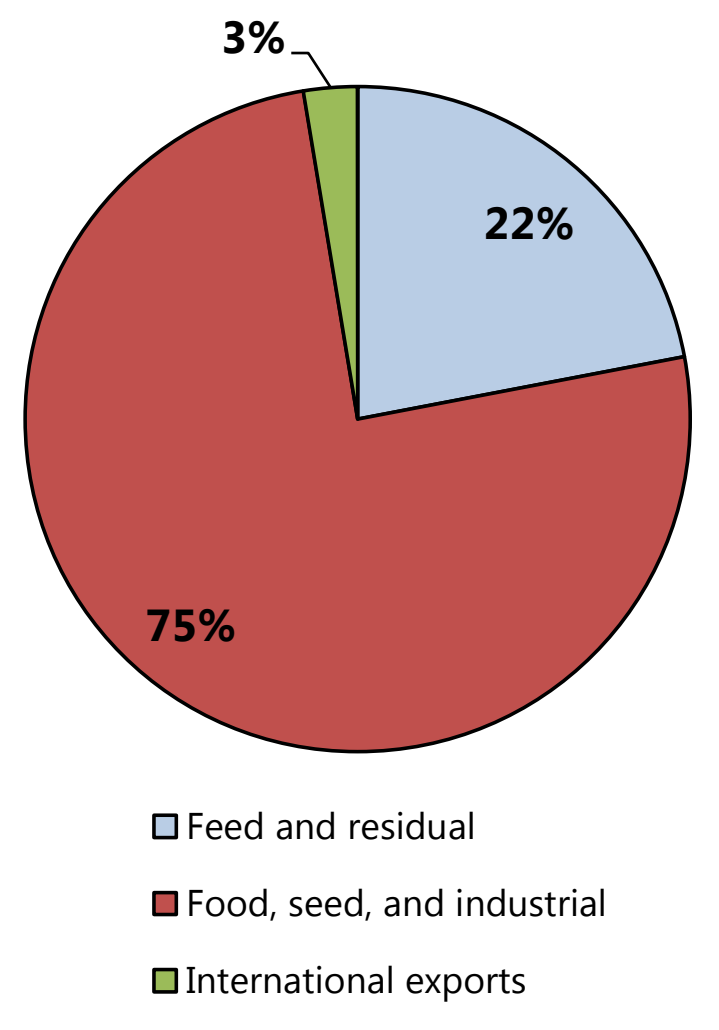

Source: USDA Economic Research Service, Feed Grains Database 


\section{Methods}

The Confidential Waybill Sample was analyzed between 1994 and 2009 for the five major grains-corn, soybean, wheat, sorghum, and barley. Movements for shipments based upon number of cars were placed in four categories by year and grain type: 1 to 5 railcars, 6 to 49 railcars, 50 to 74 railcars, and 75 or more railcars. The first category captures single-car movements. The second category captures multi-car and 26-car units. The third category captures the longer $50+$ units, and the fourth category captures the shuttle-size movements. Similarly, grain car movements by length of haul were categorized into four categories: 20 to 500 miles, 501 to 1,000 miles, 1,001 to 1,500 miles, and more than 1,500 miles. The Waybill Sample was modified to exclude records that included:

- Shipments originating outside the 48 contiguous States of the United States.

- Shipments with unusually heavy loads (equal to or more than 157.5 tons per car) or extremely light loads (equal to or less than 1 ton per car).

- Trains longer than 150 cars.

- Shipment distances less than 20 miles and more than 3,500 miles for domestic movements or 4,500 miles for export movements to Mexico or Canada. 
As domestic and export markets have evolved, railroads have continuously made efficiency strides through shuttle trains and the length of haul. Since 1994, grain and oilseed transportation has moved from small shipment sizes to shuttle-size shipments (75 or more railcars) for many grains and oilseeds, reflecting the lower costs of shuttle-size shipments, an increase in the number of domestic destinations capable of unloading shuttle-size shipments, and increased grain and oilseed exports in some years. In addition, the length of haul has increased for grains and oilseeds, reflecting competitive advantages of rail compared to truck on longer hauls, lower rail tariffs per mile for longer hauls, and changing grain and oilseed markets.

\section{Changes in Rail Shipment Sizes}

An analysis of STB waybill samples shows that corn tonnages hauled in shuttle-size shipments increased 275 percent, from 10.6 million tons in 1994 to 39.6 million tons in 2009. Over the same period, corn tonnages hauled by 1 - to 5 -railcar shipments decreased 39 percent, 6 - to 49-railcar shipments decreased 41 percent, and 50- to 74-railcar shipments decreased 4 percent.

The percentage of corn moved by shuttle-size shipments increased from 19 percent of rail corn tonnage in 1994 to 55 percent in 2009 (fig. 6). Corn shipments of 1 to 5 railcars decreased from 15 percent of the rail tonnage in 1994 to 7 percent of the total in 2009. Corn shipments of 6 to 49 railcars decreased from 41 percent of the rail tonnage to 19 percent and corn shipments of 50 to 74 railcars decreased from 26 percent to 19 percent of the rail tonnage.

Figure 6. Percentage of Corn by Rail Shipment Size

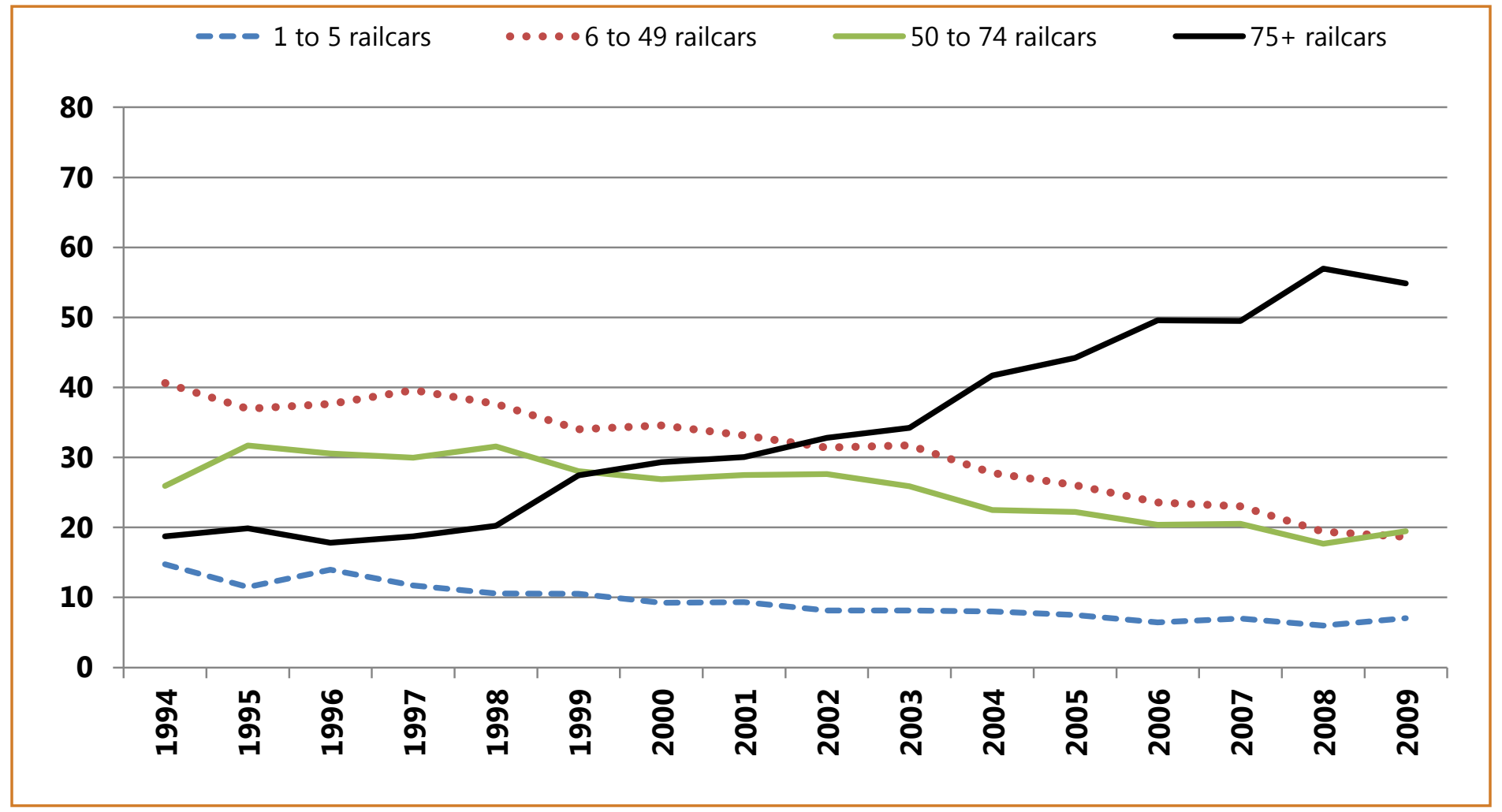

Source: USDA Analysis of Surface Transportation Board Waybill Samples 
Soybean tonnages haūled in shuttle-size shipments increased 1,127 percent, from 1.49 million tons in 1994 to 18.3 million tons in 2009. Over the same time period, soybean tonnages hauled by 1 - to 5 -railcar shipments decreased 61 percent, 6- to 49-railcar shipments decreased 16 percent, and 50- to 74-railcar shipments decreased 7 percent.

The percentage of soybeans moved by shuttle-size shipments has increased from 10 percent of total rail tonnage in 1994 to 63 percent in 2009 (fig. 7). Soybean shipments of 1 to 5 railcars decreased from 16 percent of total rail tonnage in 1994 to only 3 percent of the total in 2009. Soybean shipments of 6 to 49 railcars decreased from 44 percent of the total tonnage in 1994 to 19 percent in 2009. Soybean shipments of 50 to 74 railcars decreased from 30 percent of total rail tonnage in 1994 to 15 percent in 2009.

Figure 7. Percentage of Soybeans by Rail Shipment Size

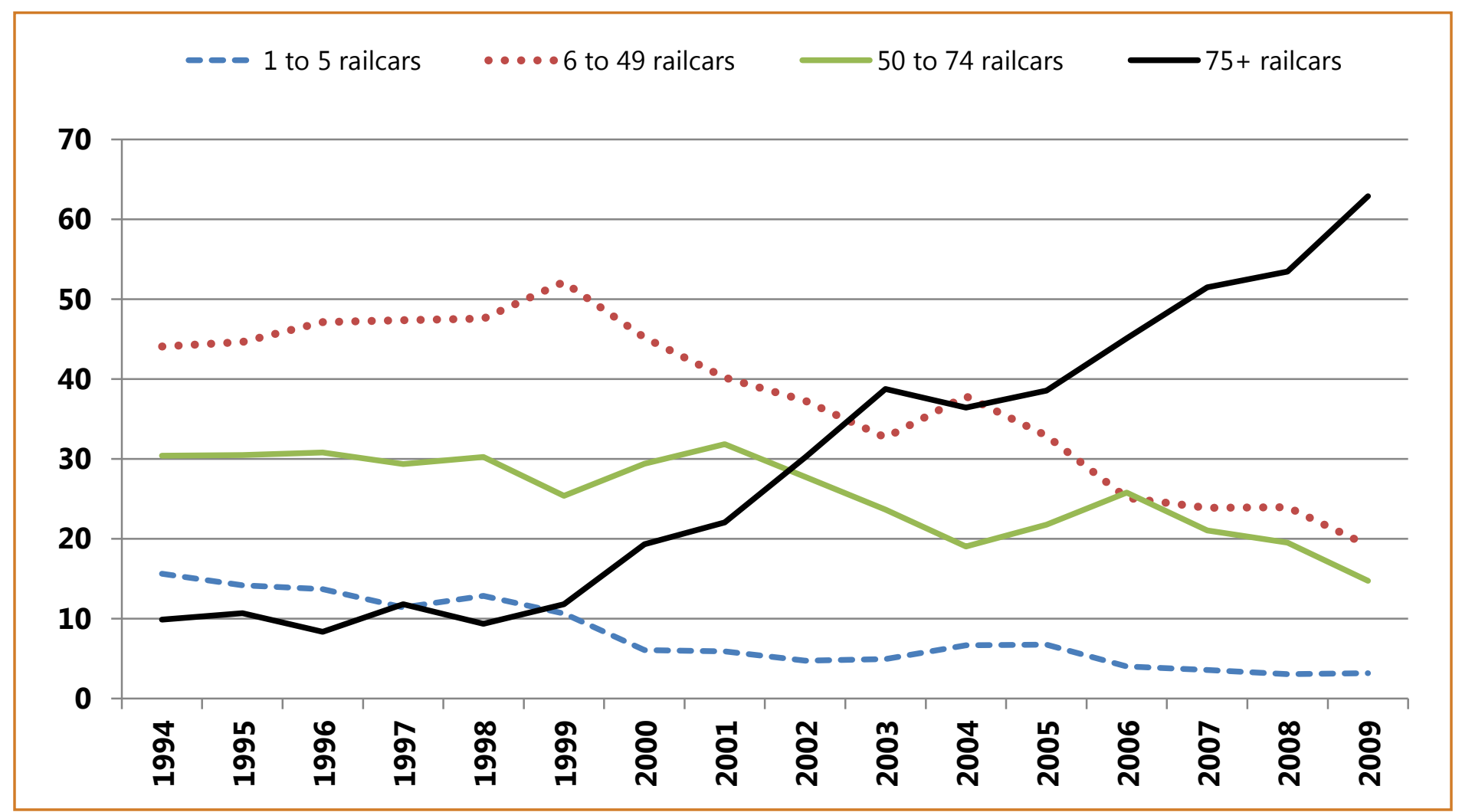

Source: USDA Analysis of Surface Transportation Board Waybill Samples

Wheat tonnages hauled in shuttle-size shipments increased 272 percent, from 4.3 million tons in 1994 to 16.1 million tons in 2009. Over the same time period, wheat tonnages hauled by 1- to 5-railcar shipments decreased 44 percent, 6- to 49-railcar shipments decreased 14 percent, and 50- to 74-railcar shipments decreased 77 percent. 
Smaller size shipments of wheat are still an important part of wheat markets. Although the percentage of wheat moved by shuttle-size shipments increased from 9 percent of the rail wheat tonnage in 1994 to 36 percent in 2009, shipment sizes of 6 to 49 railcars hauled 47 percent of the tonnage in 2009 (fig. 8). Wheat shipments of 1 to 5 railcars decreased from 20 percent of the total tonnage in 1994 to 12 percent of the total in 2009. Wheat shipments of 50 to 74 railcars decreased from 19 percent of the total rail tonnage in 1994 to only 5 percent in 2009.

Figure 8. Percentage of Wheat by Rail Shipment Size

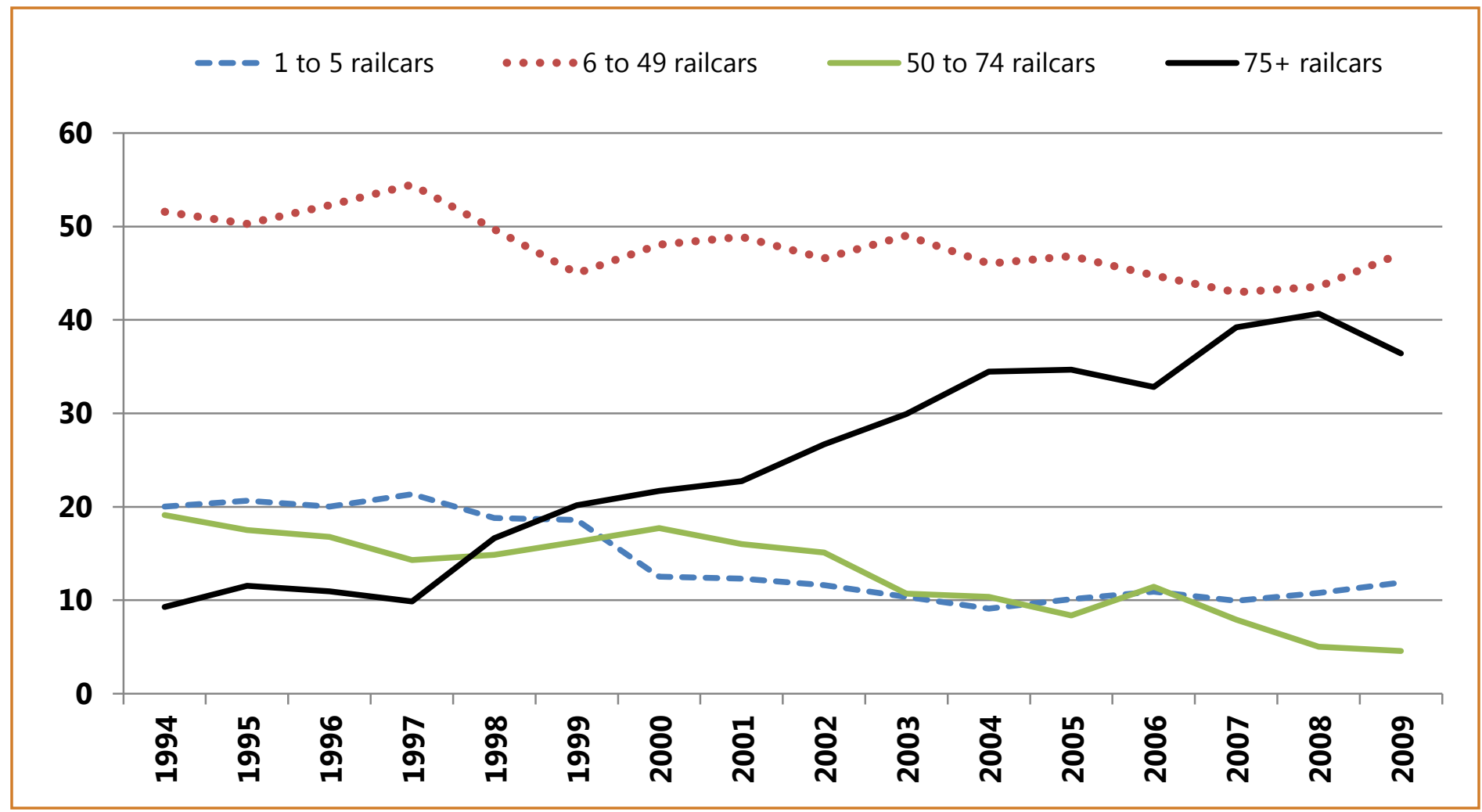

Source: $\quad$ USDA Analysis of Surface Transportation Board Waybill Samples

Sorghum tonnages hauled in shuttle-size shipments increased 174 percent, from 1.0 million tons in 1994 to 2.75 million tons in 2009. Over the same time period, sorghum tonnages hauled in 1- to 5-railcar shipments decreased 76 percent, 6- to 49-railcar shipments decreased by 86 percent, and 50- to 74-railcar shipments decreased by 89 percent.

The percentage of sorghum moved by shuttle-size shipments increased from 19 percent of the rail sorghum tonnage in 1994 to 80 percent in 2009 (fig. 9). Sorghum shipments of 1 to 5 railcars decreased from 19 percent of the rail sorghum tonnage in 1994 to 7 percent in 2009. Sorghum shipments of 6 to 49 railcars decreased from 51 percent of the rail sorghum tonnage to 11 percent, and sorghum shipments of 50 to 74 railcars decreased from 11 percent to 2 percent of the rail sorghum tonnage.

Railroad barley tonnages hauled in mid-size shipments (6 to 49 railcars) decreased 49 percent, from 4.0 million tons in 1994 to a little more than 2.0 million tons in 2009 because of a 39-percent decrease in production. Over the same time period, barley tonnages hauled in 1- to 5-railcar shipments decreased 57 percent and tonnages shipped in 50- to 75-railcar shipments decreased 100 percent.

The percentage of barley moved in 6- to 49-railcar shipments increased from 57 percent of rail barley tonnage in 1994 to 64 percent in 2009 (fig. 10). Barley shipments of 1 to 5 railcars decreased from 38 percent of rail barley tonnage in 1994 to 36 percent in 2009. Barley shipments of 50 to 74 railcars decreased from 5 percent of rail barley tonnage in 1994 to 0 percent in 2009. Shuttle-size movements rose to 4 percent of rail barley tonnage in 2008 and then returned to 0 percent in 2009. 
Figure 9. Percentage of Sorghum by Rail Shipment Size

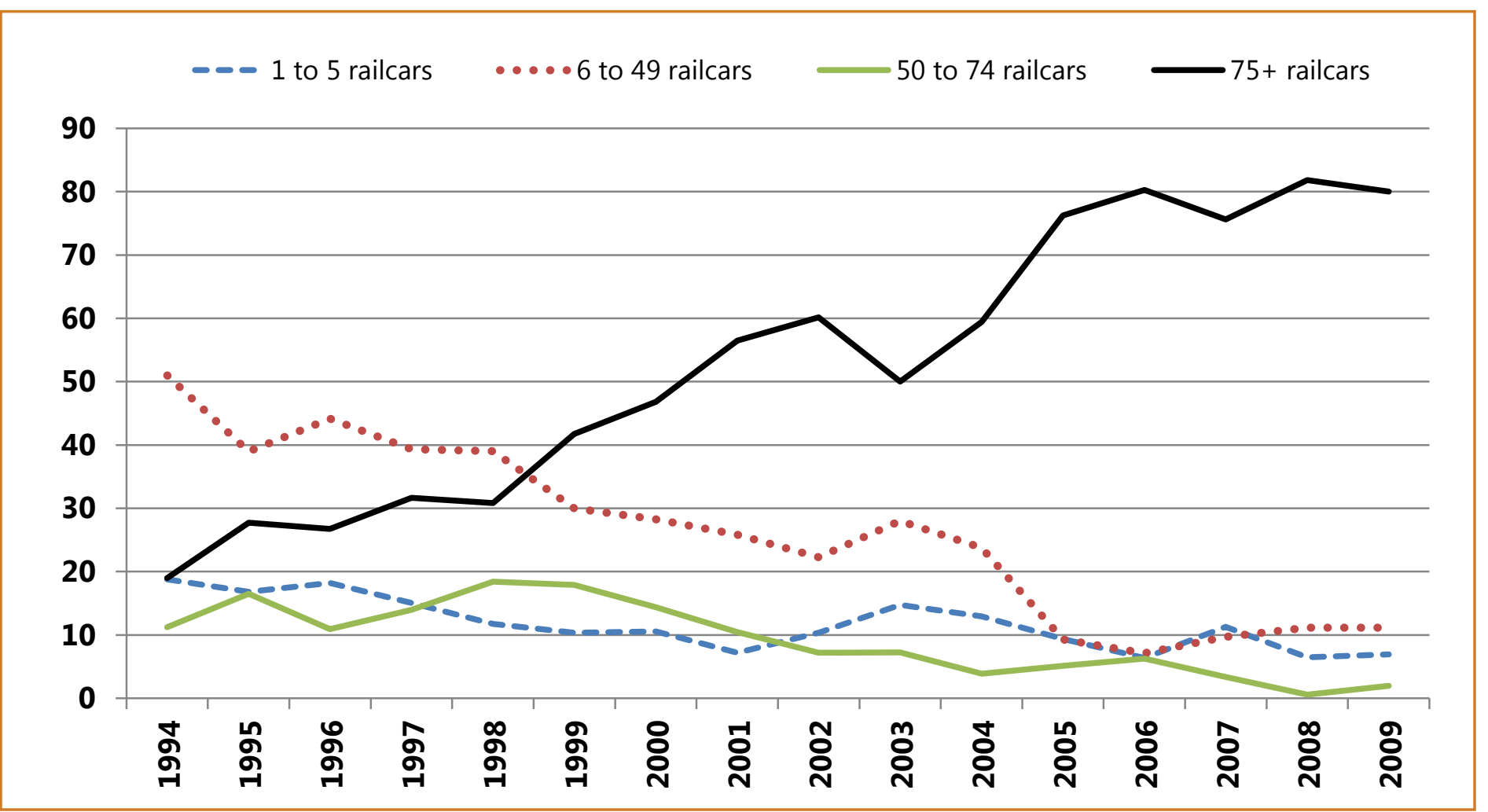

Source: USDA Analysis of Surface Transportation Board Waybill Samples

Figure 10. Percentage of Barley by Rail Shipment Size

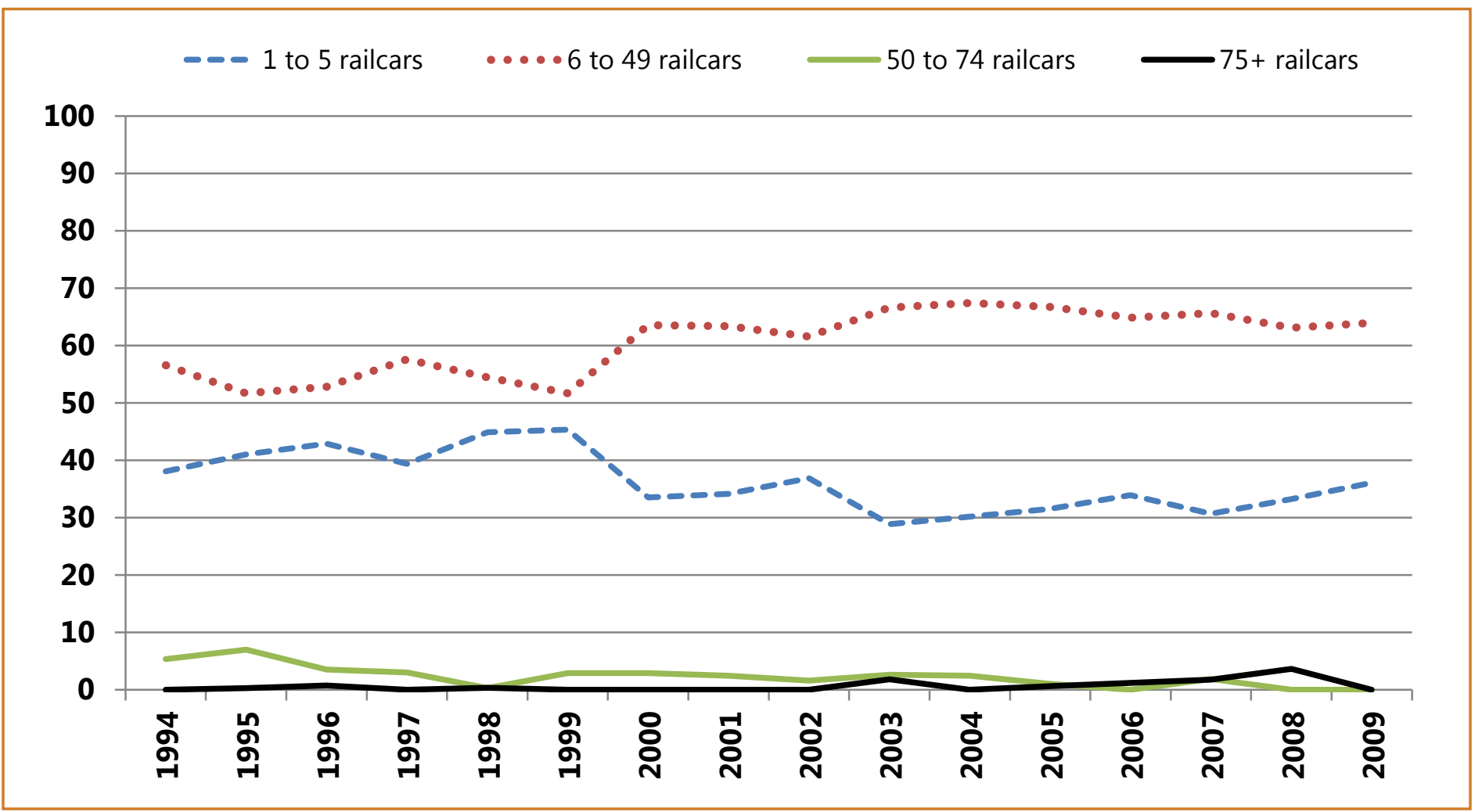

Source: USDA Analysis of Surface Transportation Board Waybill Samples 
The distance grain and oilseeds were shipped increased between 1994 and 2009, reflecting the competitive advantages of rail over truck on longer hauls, lower rail costs per mile for longer hauls, and changing grain and soybean markets. The longer hauls often move commodities to export markets and to large animal and poultry feed lots located far from major grain and oilseed production areas.

The distance corn was shipped has increased 71 percent since 1994 (table 1). Corn shipments between 20 and 500 miles, which are most susceptible to truck competition, decreased from 49 percent of the rail shipments (27.3 million tons) in 1994 to 22 percent (16.0 million tons) in 2009, a tonnage decrease of 41 percent (fig. 11). Corn tonnage moving more than 1,500 miles increased from 13 percent of the rail movements ( 7.2 million tons) in 1994 to 32 percent (23.0 million tons) in 2009, an increase in rail tonnage of 219 percent. Corn tonnage moving 1,001 to 1,500 miles increased from 8 percent of the rail movements (4.6 million tons) in 1994 to 18 percent (13.1 million tons) in 2009, an increase in rail tonnage of 188 percent. Corn tonnage moving 501 to 1,000 miles decreased from 31 percent (17.2 million tons) in 1994 to 28 percent (20.1 million tons), but rail tonnage increased 16 percent.

Figure 11. Railroad Corn Movements by Distance Shipped

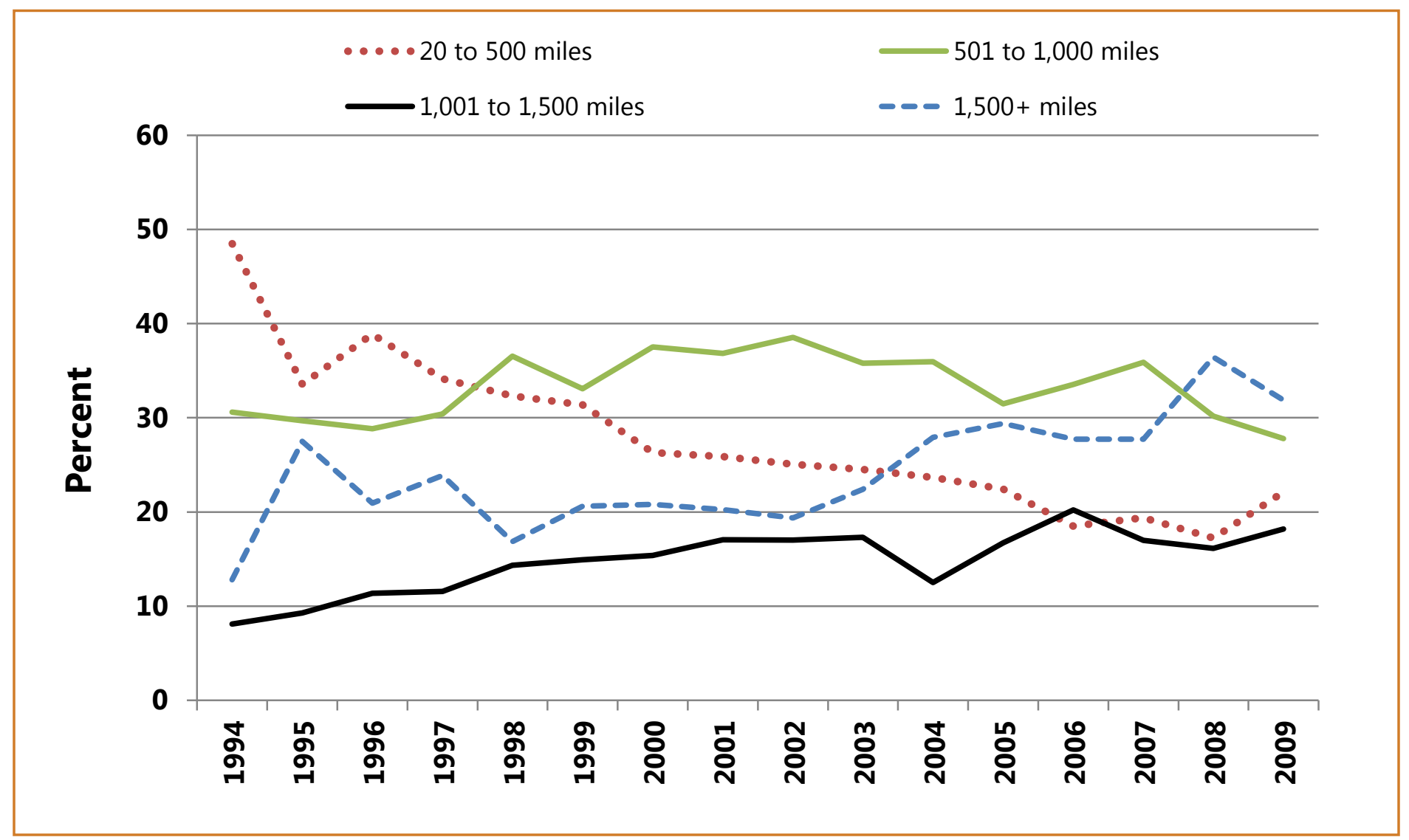

Source: USDA Analysis of Surface Transportation Board Waybill Samples

The distance soybeans are shipped has increased 123 percent (table 1), partially in response to a 79-percent increase in export tonnages since 1994. Soybean rail tonnages hauled more than 1,500 miles increased from 7 percent of total rail soybean tonnage (1 million tons) in 1994 to 45 percent (13 million tons) in 2009, a tonnage increase of 1,190 percent (fig. 12). From 1994 to 2009, the percentage of soybean rail tonnages hauled 1,001 to 1,500 miles increased from 11 percent of total rail tonnage (1.7 million tons) to 19 percent (5.4 million tons), a tonnage increase of 221 percent. The percentage of soybean rail tonnages hauled 501 to 1,000 
miles decreased from 28 percent of total tonnage (4.2 million tons) to 22 percent (6.4 million tons), but had a 51-percent increase in rail tonnage. Soybean rail tonnages hauled 20 to 500 miles decreased from 54 percent of the total rail tonnage ( 8.2 million tons) to only 15 percent (4.3 million tons), a decrease in rail tonnage of 48 percent.

Figure 12. Railroad Soybean Movements by Distance Shipped

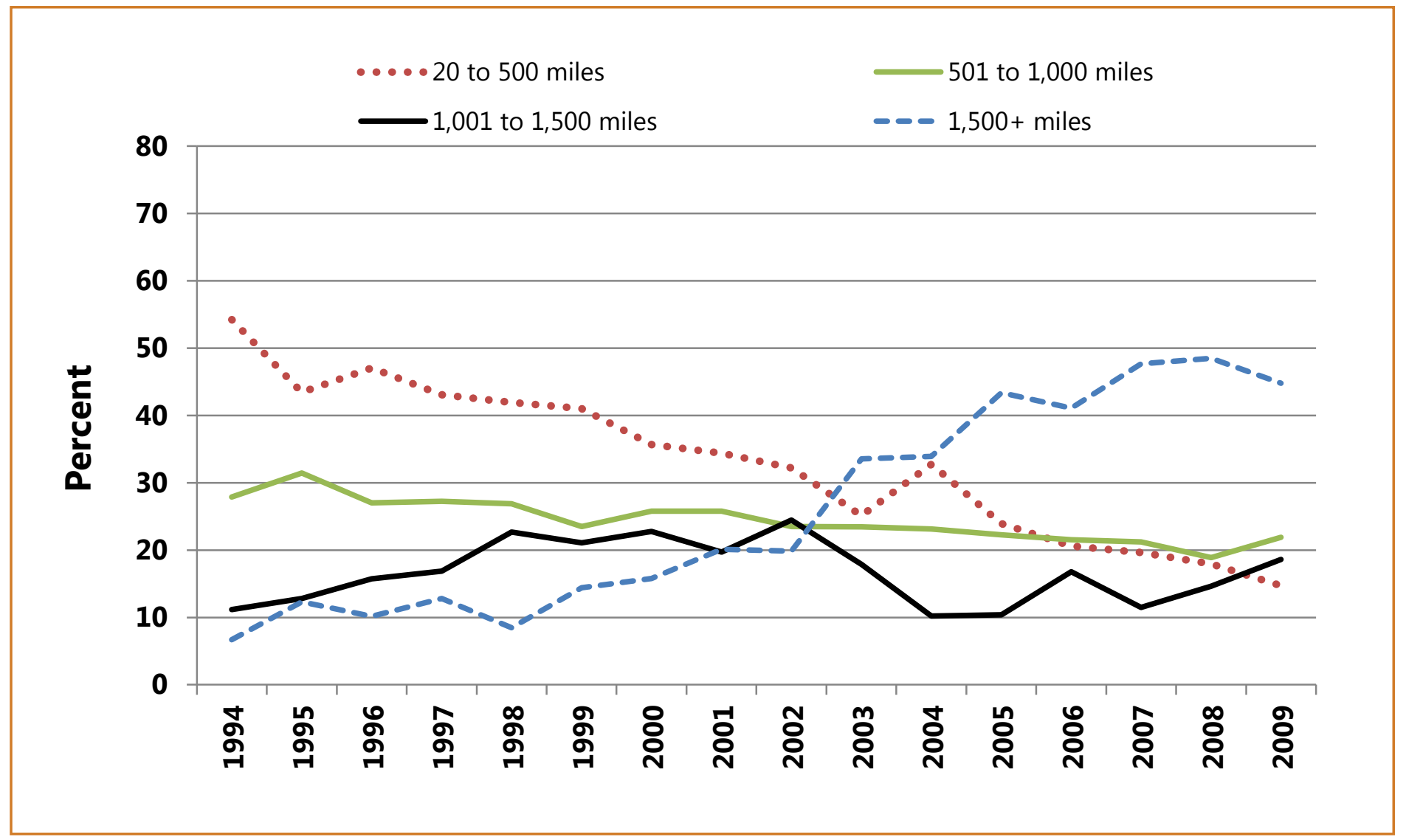

Source: USDA Analysis of Surface Transportation Board Waybill Samples

The distance wheat was shipped has increased 33 percent since 1994 (table 1). Wheat shipments between 20 and 500 miles decreased from 32 percent of the total in 1994 (15.1 million tons) to only 19 percent of the total in 2009 (8.3 million tons), a tonnage decrease of 45 percent (fig. 13). Most wheat is transported 501 to 1,000 miles, which increased from 40 percent of the total in 1994 (18.5 million tons) to 51 percent of the total in 2009 (22.7 million tons), a tonnage increase of 23 percent. The amount of wheat transported 1,001 miles to 1,500 miles decreased slightly from 20 percent in tonnage in 1994 (9.3 million tons) to 19 percent of the total in 2009 (8.3 million tons). Finally, the amount transported more than 1,500 miles increased from 8 percent of the tonnage in 1994 (3.8 million tons) to 11 percent of the tonnage in 2009 (4.9 million tons), a tonnage increase of 27 percent.

The distance sorghum was shipped increased 54 percent between 1994 and 2009 (table 1). Sorghum shipments between 20 and 500 miles, which are most susceptible to truck competition, decreased from 34 percent of sorghum rail shipments (1.78 million tons) in 1994 to 10 percent (.36 million tons) in 2009, a tonnage decrease of 80 percent (fig. 14). The percentage of sorghum rail tonnage moving 501 to 1,000 miles increased from 34 percent (1.8 million tons) in 1994 to 54 percent (1.84 million tons) in 2009, an increase in rail tonnage of 2 percent. The percentage of sorghum rail tonnage moving 1,001 to 1,500 miles decreased from 27 percent (1.4 million tons) in 1994 to 25 percent (.86 million tons) in 2009, a decrease in rail tonnage of 39 percent. The percentage of sorghum rail tonnage moving more than 1,500 miles increased from 5 percent of the rail sorghum movements (.29 million tons) in 1994 to 11 percent (.38 million tons) in 2009, an increase of 31 percent in rail tonnage. 
Figure 13. Railroad Wheat Movements by Distance Shipped

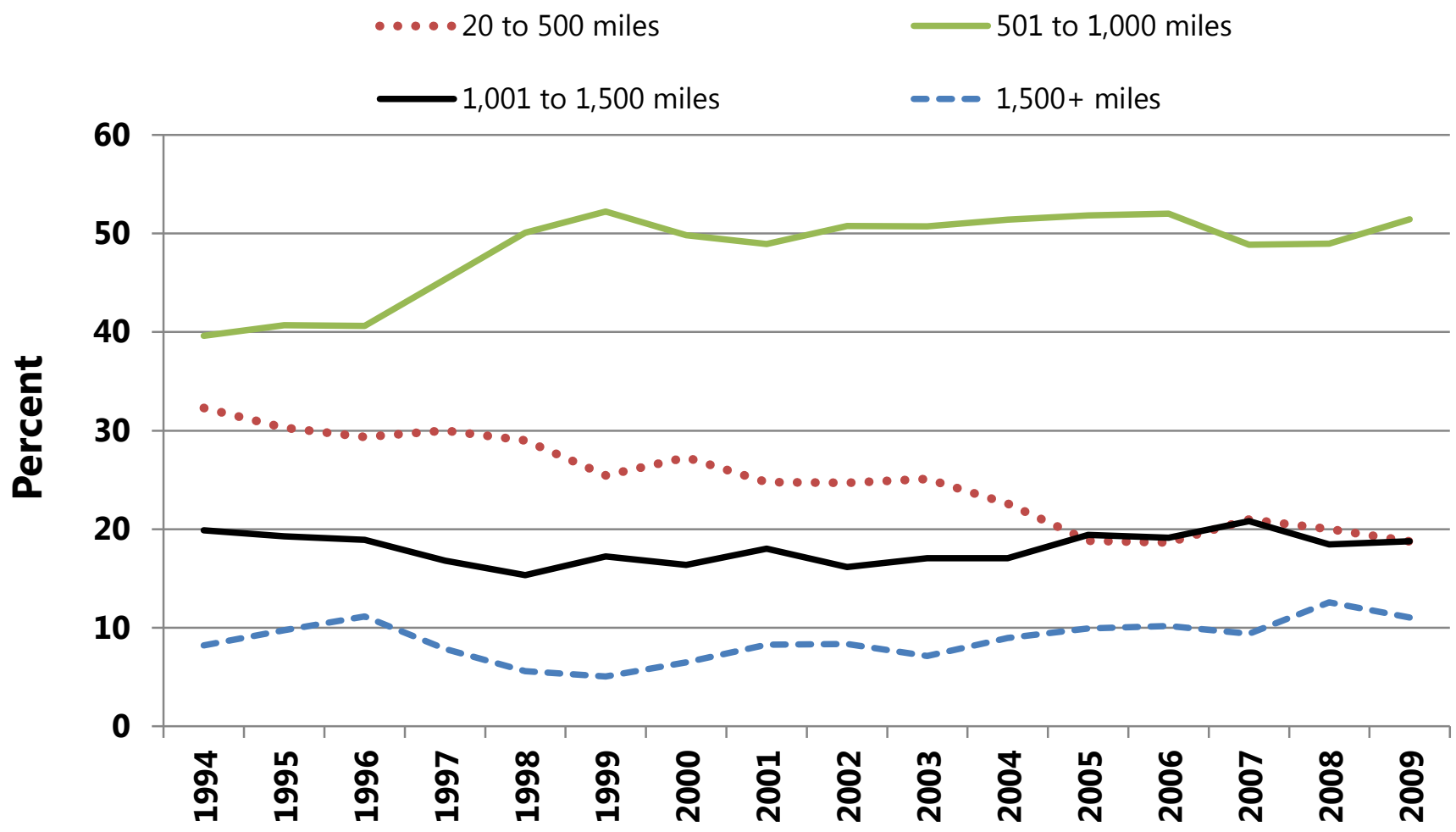

Source: USDA Analysis of Surface Transportation Board Waybill Samples

Figure 14. Railroad Sorghum Movements by Distance Shipped

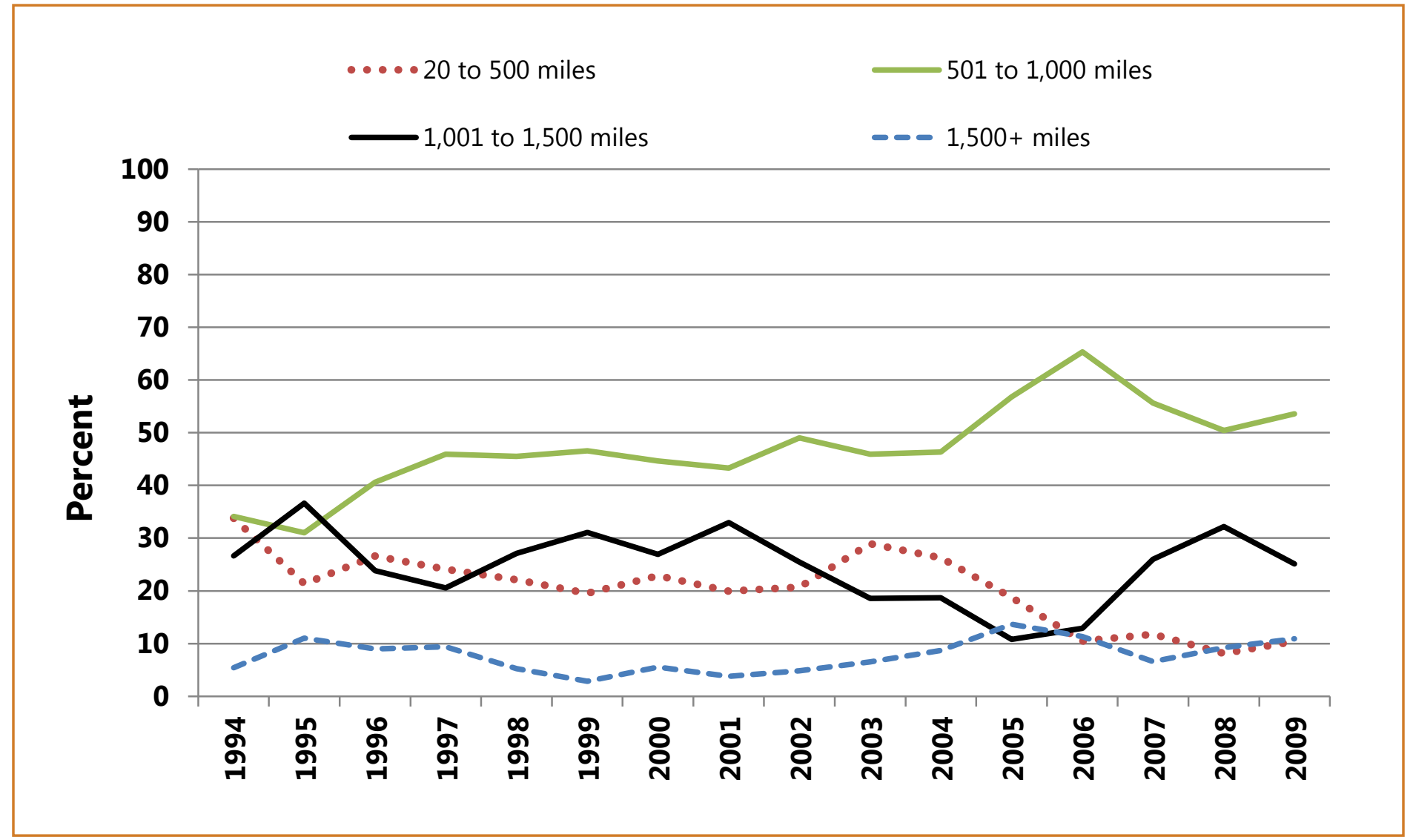


The distance barley was shipped decreased 7 percent between 1994 and 2009 (table 1). Barley rail tonnage between 20 and 500 miles decreased from 61 percent (4.29 million tons) in 1994 to 43 percent (1.38 million tons) in 2009, a decrease in tonnage of 68 percent (fig. 15). Tonnage moving between 501 to 1,000 miles increased from 19 percent of rail barley tonnage (1.32 million tons) in 1994 to 41 percent in 2009, but barley tonnage in this category still decreased 1 percent. Rail barley tonnage moving from 1,001 miles to 1,500 miles decreased from 7 percent (.51 million tons) in 1994 to 4 percent (.13 million tons) in 2009, a decrease in tonnage of 74 percent. Rail barley tonnage moving more than 1,500 miles decreased from 13 percent (.95 million tons) in 1994 to 12 percent (.38 million tons) in 2009, a tonnage decrease of 60 percent.

Figure 15. Railroad Barley Movements by Distance Shipped

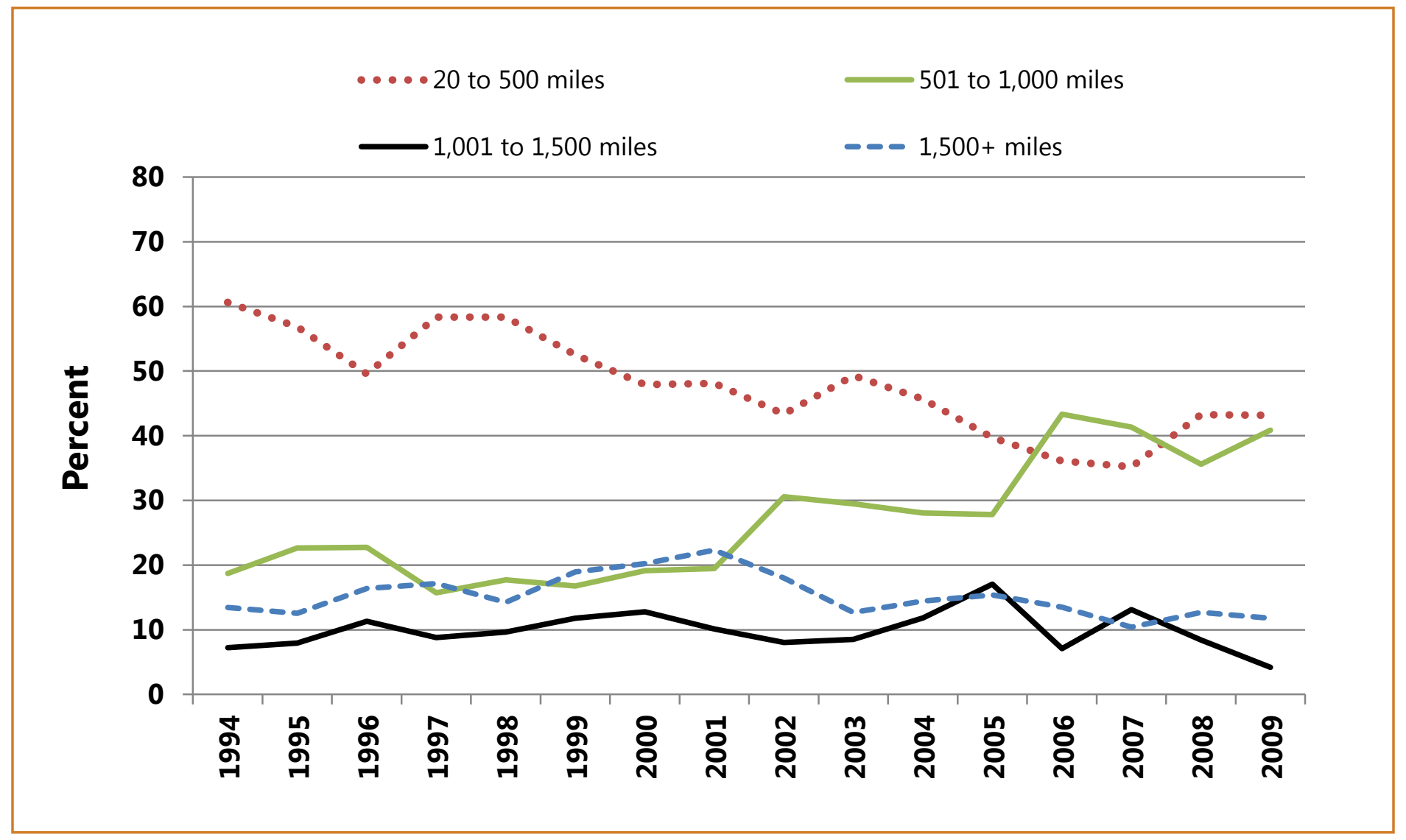

Source: USDA Analysis of Surface Transportation Board Waybill Samples

\section{Changes in Market Share of Grain Transportation}

Railroads appear to have lost a small amount of the corn market share as U.S. market year ${ }^{2}$ corn production increased 30 percent from 1994 to 2009 while the calendar year tonnage of corn moved by rail increased 28 percent. Some of this loss in market share may be because truck transportation dominates the delivery of corn to ethanol plants to be used as feedstock. From 1994 through 2009, railroads moved an average of 26 percent of corn production.

Although U.S. soybean production increased 34 percent from 1994 to 2009, soybean tonnages shipped by railroads have increased 93 percent. Rail has gained significant market share of soybean transportation, mainly because of a 79-percent increase in soybean exports. From 1994 through 2009, railroads moved an average of 25 percent of the soybean production.

2 The marketing year for corn, soybeans, and sorghum is from September 1 through August 31. The marketing year for wheat and barley is from June 1 through May 31. 
Wheat is heavily dependent upon rail transportation because much of it is grown in regions distant from markets and inland waterway transportation. From 1994 to 2009, rail transported an average of 70 percent of the wheat produced. U.S. wheat production decreased 4 percent from 1994 to 2009 and the tonnage of wheat moved by rail decreased by 5 percent. Wheat exports decreased 23 percent from 1994 to 2009.

U.S. sorghum production decreased 43 percent from 1994 to 2009 while the tonnage of sorghum moved by rail decreased by only 35 percent, indicating that railroads have gained market share. From 1994 to 2009, rail transported an average of 31 percent of the sorghum produced. During the same period, sorghum exports decreased 26 percent.

U.S. barley production decreased 39 percent from 1994 to 2009 while the barley tonnage moved by rail decreased 55 percent, indicating that railroads have lost market share. Barley is still dependent on rail transportation; 68 percent of the barley produced between 1994 and 2009 moved by rail. During the same period, barley exports have decreased 91 percent. 
This paper has studied the changes in shipment size and length of haul for five major grains between 1994 and 2009. Despite the overall push towards larger and longer hauls by the railroads to maximize efficiency, the shuttle market has not developed identically for each grain because of differences in exports, production, and usage. In 1994, the dominant size of shipment for all five grains was 6 to 49 railcars. However, there were initial differences in the lengths of haul; corn, soybeans, and barley were mostly hauled 20 to 500 miles in 1994 , and wheat and sorghum were hauled between 501 and 1,000 miles. By 2009, corn and soybeans were mostly hauled more than 1,500 miles, but the predominant category for each of the other grains did not change.

Wheat has been the most consistent of the five grains over the period of study, showing very little change in exports, production, or usage. As such, it has had the fewest changes in shipment size or length of haul; the dominant shipment size and length of haul remained the same throughout the time period. In contrast, increased production of corn and soybeans due to increases in corn-based ethanol and soybean exports have led to shuttle-sized shipments. Exports, the rise of large dairies, and shift in animal production to regions distant from corn and soybean production have resulted in lengths of haul in excess of 1,500 miles becoming the predominant categories. Soybeans have had the most dramatic change in length of haul because of the increase in exports and shipments to large animal feed regions that are not as susceptible to truck competition, as evidenced by rail's increase in market share. On the other hand, only since 2008 has corn's length of haul been predominantly more than 1,500 miles due to stronger truck competition for movements to ethanol facilities which have taken away some of rail's share.

Shuttle markets have developed differently for sorghum and barley despite decreased production in both. The use of sorghum for ethanol production and an increase in the proportion of exports among total usage have led to an increase in shuttle-sized shipments even though less sorghum is being exported overall. Barley production has declined because corn and soybeans are more profitable, and barley exports have declined for lack of a strong export demand. The predominant barley shipment size of 6 to 49 railcars and length of haul between 20 and 500 miles make rail shipment of barley more susceptible to truck competition and have caused rail to lose market share over this period. 


\section{REFERENCES}

Association of American Railroads (AAR, 2010a). Freight Commodity Statistics. (2010).

Association of American Railroads (AAR, 20xxb). The Rail Transportation of Grain. (2011, 2010, 2004).

Casavant, Ken, Eric Jessup, Marvin E. Prater, Bruce Blanton, Pierre Bahizi, Daniel Nibarger, Johnny Hill, and Isaac Weingram. "Rail Rate and Revenue Changes Since the Staggers Act." Journal of the Transportation Research Forum 50 (1), (2011): 55-77.

Kenkel, Phil, Shida Henneberry, and Haerani Agustini. "An Economic Analysis of Unit-Train Facility Investment." Paper presented at the Southern Agricultural Economics Association Annual Meeting, Tulsa, Oklahoma, February 14-18, 2004.

MacDonald, James M. "Railroad Deregulation, Innovation, and Competition: Effects of the Staggers Act on Grain Transportation." Journal of Law and Economics, 32 (1), (1989): 63-95.

Marathon, Nick and Marina R. Denicoff. U.S. Department of Agriculture, Agricultural Marketing Service (USDA/ AMS, 2011). Transportation of U.S. Grains: A Modal Share Analysis, 1978-2007. April 2011.

Prater, Marvin and Keith Klindworth. Long-Term Trends in Railroad Service and Capacity for U.S. Agriculture. USDA/Agricultural Marketing Service, 2000.

Sarmiento, C. and W. Wilson. "Spatial Modeling in Technology Adoption Decisions: The Case of Shuttle Train Elevators." American Journal of Agricultural Economics 87 (4), (2005): 1034-1045.

Surface Transportation Board (STB, 1994-2009). USDA analysis of the Confidential Waybill Sample. (19942009).

U.S. Department of Agriculture, Agricultural Marketing Service (USDA/AMS, 1998). Agricultural Transportation Challenges for the 21st Century. (1998): 25, 58.

U.S. Department of Agriculture, Economic Research Service (USDA/ERS, 1994-2009a). Feed Grains Database. (1994-2009).

U.S. Department of Agriculture, Economic Research Service (USDA/ERS, 1994-2009b). Soybean Yearbook Tables. (1994-2009).

U.S. Department of Agriculture, Economic Research Service (USDA/ERS, 1994-2009c). Wheat Yearbook Tables. (1994-2009).

U.S. Department of Agriculture and the U.S. Department of Transportation (USDA/DOT). Study of Rural Transportation Issues. April, 2010.

U.S. Department of Commerce, U.S. Census Bureau (Department of Commerce). Foreign Trade Statistics. (19942009). 
Vachal, Kim, John Bitzan, Denver Tolliver, and Bridget Baldwin. 100+ Car Marketing: An Alternative for Shipping Hard Red Spring Wheat. Ag Transportation News. Upper Great Plains Transportation Institute, North Dakota State University, 1999.

Wilson, Wesley W. and William W. Wilson. "Deregulation, Rate Incentives, and Efficiency in the Railroad Market." B. Starr McMullen ed. Transportation After Deregulation. New York: Elsevier (2001): 1-24. 
